\title{
PENGARUH GROSS DOMESTIC PRODUCT, INFLASI, SUKU BUNGA, MONEY SUPPLY, CURRENT ACCOUNT DAN CAPITAL ACCOUNTTERHADAP NILAI KURS RUPIAH INDONESIA - DOLLAR AMERIKA
}

\author{
Yunika Murdayanti*
}

\begin{abstract}
Since free-floating exchange rate system has been applied in Indonesia on August 1998, the accumulation of depreciation of rupiah against the US dollar has been about 48,7\% until December 2001. This condition brings many argumentations about the reasons behind the exchange rate instability faced by Indonesia among many experts whether it is caused by economic factors or by non-economic factors. By recognizing the causes, it will be easier for the experts and government of Indonesia to formulate the solution. This research is intended to analyze the influence of economic variables, i.e. Gross Domestic Product, money supply, interest rate, inflation rate, Current Account \& Capital Account in both Indonesia and The United State of America, as well as the position of the balance of international payment of Indonesia to the exchange rate movement in order to give contributions to solve the problem. Based on the result money supply becomes the only variable which has a multicollinearity and excluded from the regression linear. Also only current account is not significant influence on the exchange rate movement, instead of the other variables. Coefficient of determination of the research model is $84.4 \%$, means that other factors, not accommodated in this research, give $15.6 \%$ influence to the exchange rate movement. These other factors can be catagorized as other economic factors or non-economic factors.
\end{abstract}

Keywords: exchange rate, Gross Domestic Product, money supply, interest rate, inflation rate, Current Account, Capital Account

\section{PENDAHULUAN}

Pada dasarnya setiap negara di dunia saling membutuhkan untuk dapat melakukan perdagangan internasional. Faktor-faktor penting yang menjadi pendorong untuk melakukan perdagangan internasional adalah untuk memperoleh barang yang tidak dapat dihasilkan di dalam

* Yunika Murdayanti. Dosen Fakultas Ekonomi Universitas Negeri Jakarta negeri, mengimpor teknologi yang lebih modern dari negara lain, memperluas pasar produk-produk dalam negeri, dan memperoleh keuntungan spesialisasi. Setiap negara tentunya mempunyai keunggulan masing-masing dalam menghasilkan sesuatu berupa barang atau jasa. Walaupun dalam kehidupan nyata terdapat predikat negara maju dan negara 
berkembang, tidak berarti negara yang berpredikat negara maju sudah dapat memenuhi kebutuhannya sendiri. Sebagai Contoh negaranegara maju (Amerika Serikat) memerlukan karet alam, tetapi barang tersebut tidak dapat dihasilkan di negara-negara mereka. Mereka terpaksa mengimpor barangbarang tersebut dari negara-negara yang berpredikat Negara berkembang seperti Indonesia, Malaysia dan Thailand. Sebaliknya negara-negara berkembang yang lebih memiliki kekayaan alam yang luas, tapi belum mempunyai teknologi yang maju untuk dapat mengolahnya. Untuk itu, negara-negara berkembang juga harus mengimpor teknologi dari negara-negara maju. Berdasarkan alasan-alasan tersebutlah terjadi perdagangan internasional.

Kompleksitas

sistem

pembayaran dalam perdagangan internasional semakin bertambah tinggi dalam kondisi perekonomian global. Hal tersebut terjadi akibat makin besarnya volume dan keanekaragaman barang dan jasa yang akan diperdagangkan di negara lain. Oleh karena itu, upaya untuk meraih manfaat dari globalisasi ekonomi harus didahului upaya untuk menentukan kurs valuta asing pada tingkat yang menguntungkan. Penentuan kurs valuta asing menjadi pertimbangan penting bagi negara yang terlibat dalam perdagangan internasional karena kurs valuta asing berpengaruh besar pada biaya dan manfaat dalam perdagangan internasional (Sri Isnowati, $2002: 1$ ). Konsep penentuan kurs diawali dengan konsep Purchasing Power Parity (PPP), kemudian berkembang konsep dengan pendekatan neraca pembayaran (balance of payment theory). Perkembangan konsep penentuan kurs valuta asing selanjutnya adalah pendekatan moneter (monetary approach) (R. Hendra Halwani, 2002 :175).

Pendekatan moneter mempunyai dua anggapan pokok, yaitu berlakunya teori paritas daya beli dan adanya teori permintaan uang yang stabil dari sejumlah variabel ekonomi agregat. Hal tersebut berarti model pendekatan moneter terhadap kurs valuta asing dapat ditentukan dengan mengembangkan model permintaan uang dan model paritas daya beli. Di Indonesia, ada tiga sistem yang digunakan dalam kebijakan nilai tukar rupiah sejak tahun 1971 hingga sekarang tahun 2007. Antara tahun 1971 hingga 1978 dianut sistem tukar tetap ( fixed exchange rate) yang menunjukan nilai rupiah secara langsung dikaitkan dengan dollar Amerika Serikat (USD). Sejak 15 November 1978 sistem nilai tukar diubah menjadi mengambang terkendali (managed floating exchange rate) yang menunjukan nilai rupiah tidak lagi semata-mata dikaitkan dengan USD, namun terhadap sejumlah valuta partner dagang utama. Maksud sistem nilai tukar mengambang terkendali tersebut adalah bahwa, meskipun diarahkan ke sistem nilai tukar mengambang, tetap menitikberatkan unsure pengendalian. Kemudian terjadi perubahan mendasar dalam 
kebijakan mengambang terkendali terjadi pada tanggal 14 Agustus 1997. Jika sebelumnya Bank Indonesia menggunakan band sebagai guidance atas pergerakan nilai tukar, maka sejak saat itu tidak ada lagi band sebagai acuan nilai tukar. Namun demikian, cukup sulit menjawab apakah nilai tukar rupiah sepenuhnya dilepas ke pasar (free floating) atau masih akan dilakukan intervensi oleh Bank Indonesia. Dengan mengamati segala dampak sistem free floating serta dikaitkan dengan kondisi/struktur perekonomian Indonesia selama ini nampaknya purely free floating sulit untuk dilakukan. Kemungkinannya adalah Bank Indonesia akan tetap mempertahankan managed floating dengan melakukan intervensi secara berkala, selektif, dan pada timing yang tepat.

Jika dilihat dari sudut pandang pendekatan moneter, pada umumnya melihat kurs valuta asing dipengaruhi oleh variabel fundamental ekonomi, antara lain jumlah uang beredar, tingkat output riil, tingkat suku bunga, dan inflasi. Pendekatan moneter merupakan pengembangan konsep paritas daya beli dan teori kuantitas uang. Pendekatan ini menekankan bahwa, ketidakseimbangan kurs valuta asing terjadi karena ketidakseimbangan di sektor moneter yaitu terjadinya perbedaan antara permintaan uang dengan penawaran uang (jumlah uang beredar) (Mac Donald, 1990 : 86)

Berdasarkan uraian singkat tersebut, penulis tertarik untuk mengadakan penelitian tentang nilai tukar dengan menggunakan analisa fundamental. Adapun obyek penelitiannya adalah mata uang rupiah Indonesia (Rp) yang penulis pilih sebagai wakil mata uang yang lemah terhadap mata uang dollarAmerika (\$). Digunakannya dollar Amerika karena mata uang tersebut merupakan mata uang yang kuat dan Amerika merupakan partner dagang yang dominan di Indonesia, serta merupakan negara debitor terbesar di dunia.

Dengan berlandaskan nilai tukar rupiah Indonesia (Rp) - Dollar Amerika (\$), maka studi ini ingin menindaklanjuti penelitian-penelitian yang dilakukan sebelumnya sehingga terbentuk tema sentral yaitu mengetahui pengaruh variabel Gross Domestic Product, money supply, interest rate, inflation rate, dan posisi Current Account \& Capital Account pada nilai tukar antara mata uang rupiah-indonesia dengan mata uang dollar-amerika serikat.

\section{KAJIAN TEORI}

Manajemen Keuangan Perusahaan Multinasional (MNC)

Menurut Madura (2000:4), perusahaan-perusahaan secara berkesinambungan menciptakan dan menerapkan strategi-strategi baru untuk memperbaiki arus kas mereka, dalam rangka meningkatkan kekayaan pemegang saham. Sejumlah strategi mengharuskan dilakukannya ekspansi dalam pasar lokal. Strategi semacam ini biasanya dapat diimplementasikan tanpa banyak kesulitan karena informasi 
mengenai pasar telah terlebih dahulu diketahui, dan cara operasi tidak perlu banyak berubah. Strategistrategi lain mengharuskan penetrasi ke dalam pasar asing. Karena pasar luar negeri bisa sangat berbeda dari pasar lokal, pasar luar negeri menciptakan kesempatan timbulnya peningkatan arus kas perusahaan.

Banyak hambatan masuk ke dalam pasar pasar luar negeri telah dicabut atau berkurang dewasa ini, yang mendorong perusahaanperusahaan untuk memperluas perdagangan internasional (memproduksi dan menjual barangbarang di Negara asing). Akibatnya, banyak perusahaan nasional berubah menjadi perusahaan multinasional (MNC), yang didefinisikan perusahaan-perusahaan yang terlibat dalam suatu bentuk bisnis internasional. Mengingat suatu bentuk bisnis internasional menggunakan valuta asing dan yang melibatkan banyak Negara dengan nilai kurs yang berbeda-beda, maka suatu perusahaan multinasional diwajibkan mempunyai pemahaman yang luas akan pentingnya ilmu manajemen keuangan internasional. Pemahaman atas manajemen keuangan internasional sangat penting tidak hanya bagi perusahaanperusahaan multinasional besar yang memiliki banyak anak perusahaan di luar negeri, tetapi juga bagi perusahaan-perusahaan kecil yang melakukan perdagangan internasional. Perusahaan-perusahaan yang terlibat dalam bisnis internasional tentunya akan menghadapi hal-hal seperti nilai tukar, suku bunga luar negeri, biaya tenaga kerja, dan inflasi. Variabelvariabel ekonomi semacam itu dapat mempengaruhi semua kinerja perusahaan.

\section{Pasar Uang (Money Market)}

Menjelang era globalisasi, kegiatan ekspor dan impor menjadi menu seharihari bagi tiap-tiap negara. Sejalan dengan hal tersebut, konsep tentang valuta asing adalah teramat penting dikarenakan tiap negara menggunakan mata uang yang berbeda. Oleh karena itu, timbul konsep nilai tukar atau kurs (foreign exchange) yang pengertiannya menurut para ahli di antaranya Baillie (1998:126) bahwa,

"Foreign exchange is the price at which one national money can be exchanged for another"

Mengacu pada pengertian tersebut di atas, secara tidak langsung naik dan turunnya nilai suatu mata uang terhadap mata uang lain tergantung pada mekanisme yang terjadi di pasar yaitu interaksi permintaan (demand) dan penawaran (supply) mata uang asing. Permintaan uang asing bersumber dari kebutuhan valas untuk membayar impor, penanaman modal di luar negeri (capital outflow), membiayai transaksi karena berpergian ke luar negeri, transfer, membayar hutang maupun bunga dalam valas, menabung ataupun spekulasi. Penawaran uang asing bersumber antara lain dari kegiatan ekspor, penanaman modal ke dalam negeri (capital inflow), kedatangan orang asing, pemberian pinjaman. Dengan adanya permintaan 
dan penawaran uang asing (valas), terbentuklah suatu pasar yang lazim dikenal sebagai pasar uang (money market).

Adapun menurut teori ekonomi makro penentuan nilai tukar tidak hanya berdasarkan interaksi permintaan dan penawaran yang terjadi di pasar, tetapi ditentukan oleh sistem nilai tukar yang dianut oleh negara yang bersangkutan. Menurut R. Hendra Halwani (2002 : 186) sistem nilai tukar yang banyak digunakan adalah :

1. Sistem Nilai Tukar Tetap

Dalam sistem ini, lembaga otoritas moneter menetapkan tingkat nilai tukar mata uang domestik terhadap mata uang negara lain pada tingkat tertentu, tanpa memperhatikan penawaran ataupun permintaan terhadap valuta asing yang terjadi.

2. Sistem Nilai Tukar Mengambang

Dalam sistem ini, nilai tukar mata uang dibiarkan menurut keseimbangan permintaan dan penawaran mata uang asing yang terjadi. Sistem ini dibedakan menjadi dua hal. Pertama, dalam nilai tukar mengambang, pemerintah mempengaruhi tingkat nilai tukar melalui permintaan dan penawaran valuta asing atau disebut "dirty float". Kedua, disebut "clean float", pemerintah tidak mencampuri tingkat nilai tukar sama sekali, sehingga nilai tukar diserahkan pada penawaran dan permintaan valuta asing.

\section{Valuta Asing}

Valuta asing (valas) atau sering disebut foreign exchange (forex) adalah mata uang asing dan alat pembayaran lainnya yang digunakan untuk melakukan transaksi ekonomi keuangan internasional dan ada catatan nilai tukar (kurs) secara resmi pada bank sentral. Mata uang yang sering sekali digunakan dalam transaksi internasional dianggap sebagai mata uang keras (hard currency (Adwin, 2002 : 2) :

"Hard currency is a currency that is freely traded without may restrictions and for which there is usually strong external demand. Hard currencies are often called freely convertible currencies."

Jadi, mata uang tersebut nilainya stabil dan bahkan sering sekali mengalami kenaikan nilai (appreciation) terhadap mata uang lain. Pada umumnya mata uang seperti itu berasal dari negara-negara kelompok industri maju, yaitu dollarAmerika, yen-Jepang, deutchmarkjerman, poundsterling-inggris, dan franc-perancis. Sebaliknya mata uang yang jarang digunakan untuk transaksi tersebut dianggap sebagai mata uang lemah (soft currency), yang nilainya relatif tidak stabil bahkan, sering mengalami penurunan nilai (depreciation) terhadap mata uang lain.

Contoh mata uang ini adalah rupiah-Indonesia, peso-Filipina, bathThailand, yang umumnya merupakan mata uang yang berasal dari kelompok negara sedang berkembang. Terjadinya perdagangan internasional, kegiatan di pasar uang dan pasar modal serta berbagai keperluan lain yang memerlukan valuta asing, mengakibatkan timbulnya pasar valuta asing. 
Adapun definisi dari pasar valuta asing diantaranya :

1. Krugman (2000: 45)

Pasar untuk memperdagangkan mata uang internasional karena transaksi jual-beli valas diantara individu, perusahaan maupun lembaga keuangan.

2. Madura (2000: 57)

Pasar yang memfasilitasi pertukaran valuta untuk mempermudah transaksi-transaksi perdagangan dan keuangan internasional.

3. Sukirno (2002:358)

Yang disebut dengan pasar bursa valas adalah suatu bursa untuk membeli atau menjual mata uang asing (valas)

\section{Pelaku di Pasar Valuta Asing}

Pelaku-pelaku (participants) utama di pasar valuta asing menurut Krugman (2000 : 45) adalah:

1. Bank and non bank foreign exchange dealer

Para dealer yang berupa lembaga keuangan bank maupun non bank beroperasi di pasar internbank \& client mendapatkan keuntungan spread yang didapat antara harga beli (bid price) dengan harga jual (ask price) atau (offer price).

\section{Individuals and firms}

Para individuals dan firms menggunakan mata uang asing untuk memfasilitasi transaksi internasional berupa ekspor-impor dan tourisme untuk investasi. Untuk mengurangi resiko yang muncul seringkali melakukan program lindung nilai (hedging).

\section{Speculators and arbitragers}

Para speculators dan arbitragers mencari keuntungan yang didapat dengan cara keakuratan memprediksi nilai tukar yang terjadi. Untuk itu, data maupun informasi yang dapat digunakan untuk menganalisa pasar menjadi suatu hal yang sangat penting

4. Central Bank

Menggunakan caranya untuk melakukan campur tangan dalam hal penentuan nilai tukar. Hal ini disesuaikan dengan sistem nilai tukar yang dianut oleh negara yang bersangkutan.

5. Foreign Exchange Broker

Mediator perantara yang membutuhkan mata uang dengan yang akan melepas mata uangnya, yang mana keuntungan yang didapatkan berupa komisi dari hasil jual beli tersebut.

\section{Jenis Transaksi di Pasar Valuta Asing}

Berbagai jenis transaksi bisa dilakukan di pasar valuta asing, di antaranya seperti yang dijelaskan oleh Madura (2000 : 122) :

1. Transaksi Spot

Pertukaran mata uang suatu negara terhadap mata uang asing dengan penyelesaian segera. Transaksi spot ini dilakukan dengan kurs yang telah disetujui bersama dan penyelesaiannya paling lama dua hari kerja. Dalam pasar spot kurs yang ada, disesuaikan dengan kurs yang dikeluarkan bank sentral.

2. Transaksi Forward

Persetujuan antara dua pihak untuk menyerahkan valuta asing dalam jumlah tertentu di kemudian hari 
dengan kurs yang telah disepakati kedua belah pihak pada saat penanda tanganan kontrak. Waktu kontrak forward merupakan kelipatan 30 hari dan kurs forward merupakan kurs spot ditambah discount / premi yang besarnya sesuai dengan suku bunga pinjaman valuta lokal dan suku bunga deposito valas sesuai waktu yang berlaku.

\section{Transaksi Swap}

Sarana bagi otoritas moneter untuk mempertukarkan mata uang domestik dengan valas. Dalam transaksi ini, disepakati waktu penyelesaian dan nilai tukarnya yang dilakukan oleh dua bank sentral.

\section{Variabel-variabel fundamental yang Mempengaruhi Nilai Tukar Mata Uang}

1. Perbedaan tingkat inflasi

Kenaikan tingkat inflasi yang mendadak dan besar di suatu Negara akan meyebabkan meningkatnya impor oleh negara tersebut terhadap pelbagai barang dan jasa dari luar negeri, sehingga makin diperlukan banyak valuta asing untuk membayar transaksi impor tersebut. Hal ini akan mengakibatkan meningkatnya permintaan terhadap valuta asing di pasar

valuta asing (Madura,2000 : 210). Inflasi yang meningkat secara mendadak tersebut, juga memungkinkan tereduksinya kemampuan ekspor nasional negara yang bersangkutan, sehingga akan mengurangi supply terhadap valuta asing di dalam negerinya.

Berdasarkan teori paritas daya beli (purchasing power parity theory) dijelaskan bahwa, hubungan antara nilai tukar mata uang dengan inflasi dapat dirumuskan sebagai berikut :

$$
e f=\frac{1+I h}{1+I f}-1
$$

\section{(Asumsi direct quote)}

ef = Besarnya apresiasi atau depresiasi nilai kurs asing

Ih = Inflasi domestik

If = Inflasi yang terjadi di luar negeri

Menurut teori tersebut, tingkat inflasi domestik yang melebihi tingkat inflasi di luar negeri akan mengakibatkan nilai kurs domestik terdepresiasi terhadap mata uang asing.

2. Perbedaan tingkat suku bunga Perubahan tingkat suku bunga akan berdampak pada perubahan jumlah investasi di suatu negara, baik yang berasal dari investor domestic maupun investor asing, khususnya pada jenis-jenis investasi portofolio, yang umumnya berjangka pendek. Perubahan tingkat suku bunga ini akan berpengaruh pada perubahan jumlah permintaan dan penawaran di pasar uang domestik. Dan, apabila suatu negara menganut rezim devisa bebas, maka hal tersebut juga memungkinkan terjadinya peningkatan aliran modal masuk (capital inflow) dari luar negeri. Hal ini akan menyebabkan terjadinya perubahan nilai tukar mata uang negara tersebut terhadap mata uang asing di pasar valuta asing (Madura,2000 : 222) . Dalam beberapa kasus, bahkan perubahan 
nilai tukar mata uang antara dua negara dapat juga dipengaruhi oleh perubahan tingkat suku bunga yang terjadi di Negara ketiga. Tingkat suku bunga rill umumnya lebih sering dibandingkan antar negara guna mengukur pergerakan nilai tukar mata uang. Secara teoretis akan terjadi korelasi yang signifikan antara perbedaan tingkat suku bunga di dua negara dengan nilai tukar mata uangnya terhadap mata uang Negara yang lain.

Berdasarkan pada prinsip International Fisher's Effect, dapat dirumuskan bahwa :

$$
e f=\frac{1+I h}{1+I f}-1
$$

\section{(Asumsi direct quote)}

ef = Besarnya apresiasi atau depresiasi nilai kurs asing

ih = tingkat suku bunga domestik

if = tingkat suku bunga di luar negeri

3. Perbedaan tingkat pendapatan nasional (Gross Domestic Product)

Produk domestik bruto (Gross Domestic Product) merupakan jumlah produk berupa barang dan jasa yang dihasilkan oleh unit-unit produksi di dalam batas wilayah suatu negara (domestik) selama satu tahun. Dalam perhitungan GDP ini, termasuk juga hasil produksi barang dan jasa yang dihasilkan oleh perusahaan/orang asing yang beroperasi di wilayah Negara yang bersangkutan. Barangbarang yang dihasilkan termasuk barang modal yang belum diperhitungkan penyusutannya, karenanya jumlah yang didapatkan dari GDP dianggap bersifat bruto/kotor. Dalam pendekatan moneter, perbedaan tingkat pendapatan nasional di dua Negara akan dapat mempengaruhi transaksi ekspor dan impor barang, maupun transaksi aset lintas negara yang bersangkutan. Hal tersebut selanjutnya dapat mempengaruhi perubahan jumlah permintaan dan penawaran valuta asing di negaranegara tersebut, yang otomatis juga akan berpengaruh terhadap nilai kurs yang berlaku pada sistem kurs mengambang bebas. Dengan kata lain jumlah pertumbuhan output rill di suatu Negara sangat mempengaruhi jumlah permintaan uang domestik dari luar negeri yang membuat jumlah penawaran uang semakin berharga, dan akan memicu terjadinya apresiasi mata uang domestik (Salvatore, 1997 : 323).

4. Perbedaan jumlah uang beredar Total kuantitas uang dalam suatu perekonomian pada suatu titik tertentu. Secara teoritis diwujudkan dalam M1, M2, dan M3 yang mana menurut (Salvatore, 1997 : 323) yang dimaksud dengan M1 adalah semua uang kartal dan uang giral, dimana uang kartal adalah uang kertas dan koin yang dicetak dan diedarkan oleh bank sentral, sedangkan uang giral adalah uang yang diciptakan oleh bank umum melalui lintas giral. M2 adalah M1 ditambah tabungan dan berbagai macam deposito yang berjangka pendek. Dan M3 adalah M2 ditambah beberapa komponen seperti 
sertifikat deposito. Dalam pendekatan moneter, yang mendasarkan kebijakan kurs mengambang bebas, bahwa nilai tukar aktual mata uang dari suatu Negara dalam satuan mata uang negara lain ditentukan oleh pertumbuhan penawaran uang dan permintaan uang. Jumlah uang beredar yang berlebihan dalam suatu negara akan menyebabkan nilai tukar mata uangnya melemah (depresiasi), karena tidak diimbangi dengan permintaan yang sesuai, sebalikya jika permintaan akan mata uang lebih besar daripada jumlah kenaikan penawaran uang, maka nilai tukarnya akan menguat (apresiasi) (Salvatore, 1997 : 323). Dalam contoh kasus, pertumbuhan penawaran uang suatu negara yang lebih tinggi dibandingkan tingkat output rill-nya, maka mata uang negara tersebut akan mengalami depresiasi, hal itu disebabkan karena terjadi kelebihan penawaran uang dibandingkan dengan permintaannya. Sebaliknya, jika di suatu negara pertumbuhan penawaran uangnya lebih rendah dibandingkan dengan tingkat output rillnya, maka mata uang tersebut akan mengalami apresiasi, hal itu disebabkan karena terjadinya kelebihan permintaan dibandingkan dengan penawaran.

\section{Posisi neraca pembayaran (balance} of payment)

Neraca Pembayaran (balance of payment) adalah ukuran dari semua transaksi antara penduduk dalam negri dengan penduduk luar negri selama periode waktu tertentu. Neraca pembayaran dibagi menjadi dua komponen, yaitu neraca berjalan dan neraca modal.

Neraca berjalan (current account) adalah ukuran perdagangan barang dan jasa internasional suatu negara yang paling luas. Komponen utamanya adalah neraca perdagangan, yaitu selisih antara ekspor dan impor. Jika impor lebih tinggi dari ekspor, maka yang terjadi adalah defisit neraca perdagangan. Sebaliknya jika ekspor lebih tinggi dari impor, yang terjadi adalah surplus.

Neraca modal (capital
account)
perubahanperubahan mencerminkan

kepemilikan aset jangka pendek dan jangka panjang. Investasi luar negeri jangka panjang mengukur semua investasi modal antarnegara, termasuk investasi asing langsung dan pembelian sekuritas yang berjangka waktu jatuh tempo lebih dari 1 tahun. Invetasi asing jangka pendek mengukur arus dana yang diinvestasikan dalam sekuritassekuritas yang berjangka waktu kurang dari setahun. Karena jangka waktu jatuh temponya yang pendek, investor-investor sekuritas semacam itu biasanya menahan dana mereka dalam suatu negara tertentu untuk jangka waktu yang tidak lama, yang menyebabkan arus investasi jangka pendek sangat bergejolak.

Dalam kondisi sistem nilai tukar yang berfluktuasi secara bebas, nilai tukar diantara dua mata uang seperti juga komoditi yang lain ditentukan oleh saling pengaruh diantara permintaan dan penawaran. Permintaan valas ditentukan / berasal 
dari individu-individu atau perusahaan-perusahaan yang melakukan pembayaran pada pihak luar dengan valas. Transaksi yang termasuk adalah seperti impor barang dan jasa, pembelian surat berharga luar negeri. Pencatatan transaksi tersebut pada sisi debit di neraca pembayaran. Sedangkan penawaran diturunkan dari penerimaan currency dari hasil ekspor barang dan jasa, penjualan sekuritas keuangan kepada pihak asing. Pencatatan transaksi tersebut pada sisi kredit di neraca pembayaran. Jadi nilai tukar yang berlaku disesuaikan pada titik impas antara permintaan dan penawaran. Dengan kata lain, Hasil surplus menunjukan adanya aliran valuta asing yang masuk netto di dalam perekonomian negara tersebut melalui transaksi financial \& assets, sedangkan hasil defisit menandakan telah terjadi aliran dana keluar netto ke luar negeri. ( Krugman, 2000 : 23).

\section{Ringkasan Penelitian Terdahulu}

1. Adwin Surja Atmaja, 2002 diperoleh hasil bahwa hanya variabel jumlah uang beredar yang memiliki pengaruh yang signifikan terhadap pergerakan nilai tukar rupiah terhadap dolar Amerika, sedangkan variabel variabel yang lainnya tidak. Dengan koefisien determinasi sebesar 32,5\% mengindikasikan, bahwa $67,5 \%$ dari variabel terikatnya dipengaruhi oleh faktor-faktor selain faktor ekonomi yang dalam penelitian ini menjadi variabel bebas.
Faktor-faktor lain tersebut bisa dikategorikan dalam faktor ekonomi lainnya maupun faktorfaktor non ekonomi.

2. Sri Inowati, 2002 : Analisis Faktor-faktor yang Mempengaruhi Nilai Tukar Rupiah Terhadap Dollar Amerika dijelaskan bahwa variabel perbedaan jumlah uang beredar adalah berpengaruh terhadap nilai tukar dalam jangka pendek sedangkan dalam jangka panjang variabel ini tidak mampu menerangkan perilaku nilai tukar.

3. Hadi Kardoyo, 2003 : variabel fundamental ekonomi jumlah uang beredar (JUB), tingkat pendapatan nasional, dan tingkat suku bunga, serta signifikannya variabel-variabel fundamental ekonomi tersebut dalam menjelaskan fluktuasi kurs Rp/US\$ yaitu paritas suku bunga (interest rate parity) berlaku dalam mempengaruhi fluktuasi kurs valas Rp/US\$, Variabel tingkat inflasi Indonesia terhadap inflasi Jepang dan Amerika bertanda positif dan signifikan. Ini berarti doktrin paritas daya beli (purchasing power parity) juga berlaku dalam mempengaruhi fluktuasi kurs Rp/Yen serta Rp/US\$.

4. Tri Wibowo dan Hidayat Amir, 2005 Pengujiannya atas beberapa model menghasilkan model terbaik bahwa faktorfaktor yang mempengaruhi besaran nilai tukar rupiah terhadap US\$ adalah selisih 
pendapatan riil Indonesia dan Amerika, selisih inflasi Indonesia dan Amerika, selisih tingkat suku bunga Indonesia dan Amerika, serta nilai tukar rupiah terhadap US\$ satu bulan sebelumnya (lag $-1)$.

\section{Perumusan Hipotesa}

$\mathrm{H} 1$ : Ada pengaruh yang signifikan antara menguatnya nilai tukar rupiah terhadap dollar Amerika dengan semakin tingginya tingkat perubahan output rill di Indonesia dibandingkan dengan tingkat perubahan output rill di Amerika.

$\mathrm{H} 2$ : Ada pengaruh yang signifikan antara menguatnya nilai tukar rupiah terhadap dollar Amerika dengan semakin besarnya tingkat jumlah uang beredar di Indonesia dibandingkan dengan tingkat jumlah uang beredar di Amerika.

H3 : Ada pengaruh yang signifikan antara menguatnya nilai tukar rupiah terhadap dollar Amerika dengan semakin tingginya tingkat suku bunga di Indonesia dibandingkan dengan tingkat suku bunga di Amerika.

$\mathrm{H} 4$ : Ada pengaruh yang signifikan antara melemahnya nilai tukar rupiah terhadap dollar Amerika dengan semakin tingginya tingkat inflasi di Indonesia dibandingkan dengan tingkat inflasi Amerika

H5 : Ada pengaruh yang signifikan antara menguatnya nilai tukar rupiah terhadap dollar amerika dengan semakin besarnya nilai surplus current account BOP Indonesia

$\mathrm{H} 6$ : Ada pengaruh yang signifikan antara menguatnya nilai tukar rupiah terhadap dollar amerika dengan semakin besarnya nilai surplus capital account BOP Indonesia

\section{METODE PENELITIAN}

Penelitian yang digunakan dalam skripsi ini adalah komparatif kausalitas, penelitian ini menggunakan pendekatan studi kasus yaitu melakukan penelitian yang rinci mengenai suatu obyek tertentu selama kurun waktu tertentu. Penelitian ini bertujuan untuk mengetahui pengaruh variabelvariabel ekonomi pada nilai tukar mata uang rupiah pada dollar Amerika dan yen Jepang. Penelitian ini bersifat penelitian kuantitatif yaitu penelitian yang menekankan pada pengujian teori melalui pengukuran variabel dengan angka dan melakukan analisis data dengan menggunakan prosedur statistik.

Data yang dipergunakan adalah data sekunder berupa data triwulanan yang dikumpulkan dari beberapa sumber, yaitu :

- Statistik Ekonomi Dunia (Econstats), yaitu data statistik tentang perekonomian negaranegara di dunia yang dipublikasikan melalui website. Penulis mengakses data untuk periode tri-wulan I tahun 1999 sampai dengan tri-wulan 4 tahun 2006.

- Laporan indikator makroekonomi dunia yang diterbitkan oleh Bank Indonesia

- Indikator Ekonomi dan Biro Pusat Statistik. 


\section{Identifikasi Pengolahan Data}

Langkah pertama dalam pengolahan data kuartalan mengenai nilai tukar rupiah terhadap dollar AS dan yen-jepang, tingkat suku bunga, tingkat inflasi, output rill, peredaran uang, dan neraca pembayaran Indonesia periode tri-wulanan 1999 2006.

Langkah kedua adalah
menghitung masing-masing hubungan antar variable dengan analisis regresi linier berganda. Tahapan penyusunan regresi linear berganda meliputi :

1. Menentukan variabel bebas (independen) dan variable tergantung (dependen)

2. Uji Asumsi Klasik

3. Menentukan model pembuatan model regresi

4. Interpretasi Model Regresi Berganda

5. Menguji signifikansi model (uji T, uji F, dan sebagainya)

\section{Identifikasi Variabel Penelitian}

a. Nilai tukar atau kurs (exchange rate)

Harga suatu mata uang terhadap mata uang lain atau banyaknya mata uang yang harus dikorbankan untuk mendapatkan mata uang lainnya. Kurs yang digunakan adalah nilai kurs rupiah Indonesia-dollar Amerika (IDR/USD) dan rupiah Indonesia-yen Jepang (IDR/JPY). Data diperoleh dari kepustakaan Bank Indonesia (BI)

b. Output rill (gross domestic product real)
Pendapatan nasional yang dihitung dengan pendekatan output yaitu jumlah dari seluruh nilai tambah dalam ekonomi atau nilai dari barang final yang diproduksi dalam suatu wilayah (negara) secara geografis. Data diperoleh dari website econstat . Dalam penelitian ini nilai output rill Amerika dan Jepang telah dikonversi dalam mata uang rupiah dengan menggunakan kurs pada periode tersebut

c. Jumlah uang beredar (money supply)

M2 adalah M1 ditambah tabungan dan berbagai macam deposito yang berjangka pendek. Data diperoleh dari Bank Indonesia Dalam penelitian ini nilai money supply Amerika dan Jepang telah dikonversi dalam mata uang rupiah dengan menggunakan kurs pada periode tersebut

\section{d. Tingkat bunga (interest rate)} Harga yang dibayarkan per satuan mata uang yang dipinjam per periode waktu tertentu, dinyatakan dalam persentase. Perhitungan ini muncul karena adanya konsep nilai waktu uang (time value of money). Tingkat bunga menggunakan suku bunga PUAB (Pasar Uang Antar Bank) untuk Indonesia, dan suku bunga diskonto untuk Amerika dan Jepang. Data diperoleh dari Bank Indonesia.

e. Tingkat inflasi (inflation rate)

Persentase kenaikan harga dalam indeks relevan dari periode pertama ke periode kedua. Data 
diperoleh dari Bank Indonesia dan Biro Pusat Statistik.

\section{f. Balance of payment (Current Account)}

Current Account menunjukan kinerja transaksi perdagangan barang dan jasa internasional. Hasil surplus menunjukan adanya aliran valuta asing yang masuk netto di dalam perekonomian negara tersebut melalui transaksi barang dan jasa, sedangkan hasil defisit menandakan telah terjadi aliran dana keluar netto ke luar negeri. Data diperoleh dari Bank Indonesia dalam mata uang dollar Amerika.

\section{g. Balance of Payment (Capital Account)}

Capital Account menunjukan kinerja transaksi financial \& assets internasional. Hasil surplus menunjukan adanya aliran valuta asing yang masuk netto di dalam perekonomian negara tersebut melalui transaksi financial \& assets, sedangkan hasil defisit menandakan telah terjadi aliran dana keluar netto ke luar negeri. Data diperoleh dari Bank Indonesia dalam mata uang dollar Amerika

\section{Tehnik Analisa Data}

$$
\begin{gathered}
Y=\beta 0+\beta 1\left(y t-y t^{*}\right)-\beta 2\left(m t-m t^{*}\right)+ \\
\beta 3(\text { rt-rt*) }-\beta 4(\text { it-it*) }+\beta 5(\text { bop } 1)+ \\
\beta 6(\text { bop2) }+\varepsilon
\end{gathered}
$$

Keterangan :

$\mathrm{Y}=$ Nilai tukar Rupiah IndonesiaDollar Amerika

$\beta 0=$ Suatu konstanta

$\beta 1=$ Koefisien perbedaan output rill

$$
\begin{aligned}
& \text { yt } \quad=\text { GDP Indonesia } \\
& \mathrm{yt}^{*}=\text { GDP Amerika Serikat } \\
& \beta 2=\text { Koefisien perbedaan jumlah } \\
& \text { uang beredar } \\
& \mathrm{mt}=\text { Jumlah uang beredar } \\
& \text { Indonesia } \\
& \mathrm{mt}^{*}=\text { Jumlah uang beredar Amerika } \\
& \text { Serikat } \\
& \text { B3 = Koefisien perbedaan tingkat } \\
& \text { bunga } \\
& \text { rt = Tingkat bunga Indonesia } \\
& \mathrm{rt}^{*}=\text { Tingkat bunga Amerika } \\
& \text { Serikat } \\
& \beta 4=\text { Koefisien perbedaan tingkat } \\
& \text { inflasi } \\
& \text { it } \quad=\text { Tingkat inflasi Indonesia } \\
& \text { it* }=\text { Tingkat inflasi Amerika Serikat } \\
& \beta 5=\text { Koefisien besarnya } \\
& \text { surplus/defisit current } \\
& \text { account BOP } \\
& \text { bop1 = Besarnya surplus atau defisit } \\
& \text { current account BOP } \\
& \text { Indonesia } \\
& \beta 6=\text { Koefisien besarnya } \\
& \text { surplus/defisit capital account } \\
& \text { BOP } \\
& \text { bop2 = Besarnya surplus atau defisit } \\
& \text { capital account BOP } \\
& \text { Indonesia }
\end{aligned}
$$

\section{HASIL DAN PEMBAHASAN Uji Asumsi Klasik}

Sebelum melakukan regresi berganda, peneliti terlebih dahulu melakukan uji asumsi klasik untuk melihat apakah data penelitian bersifat BLUE atau tidak. Uji asumsi klasik yang dilakukan antara lain : uji normalitas, uji multikolinearitas, uji heteroskedastisitas dan uji 
autokorelasi. Pada pengujian uji multikolinearitas terdapat variabel M2 yaitu variabel jumlah uang beredar (money supply) yang memiliki masalah muktikolinearitas yang tinggi, sehingga untuk selanjutnya variabel M2 tidak diikutsertakan pada uji selanjutnya agar dapat dihasilkan pengujian yang BLUE.

\section{Uji Hipotesis}

\begin{tabular}{|l|r|r|r|r|}
\multicolumn{7}{|c|}{ Model Summary } \\
\hline Model & $\mathrm{R}$ & \multicolumn{1}{c|}{ R Square } & Adjusted R Square & $\begin{array}{c}\text { Std. Error of the } \\
\text { Estimate }\end{array}$ \\
\hline 1 & $.932^{\mathrm{a}}$ & .869 & .844 & 303.87780 \\
\hline
\end{tabular}

a. Predictors: (Constant), GDP, BOP1, BOP2, Inflasi, Interest

Koefisien Determinasi

Angka adjusted $\mathrm{R}$ sebesar 0,844 menunjukan bahwa korelasi / hubungan nilai tukar Rp / USD dengan lima variabel independen-nya adalah sangat kuat. Angka adjusted $R$ square atau koefisien determinasi adalah 0.844 . Berarti hampir $84.4 \%$ perubahan nilai tukar Rp/USD disebabkan oleh variabel-variabel independen-nya, sedangkan sisanya $15.6 \%$ dijelaskan oleh sebab-sebab lain seperti faktor-faktor politik, hankam, sosial budaya, dan sebagainya.

ANOVA $^{\mathrm{b}}$

\begin{tabular}{|c|c|c|c|c|c|c|}
\hline & & $\begin{array}{l}\text { Sum of } \\
\text { Squares }\end{array}$ & $\mathrm{df}$ & Mean Square & $\mathrm{F}$ & Sig. \\
\hline \multirow[t]{3}{*}{1} & Regression & $1.596 \mathrm{E} 7$ & 5 & 3192421.792 & 34.572 & $.000^{\mathrm{a}}$ \\
\hline & Residual & 2400884.607 & 26 & 92341.716 & & \\
\hline & Total & $1.836 \mathrm{E} 7$ & 31 & & & \\
\hline
\end{tabular}

a. Predictors: (Constant), GDP, BOP1, BOP2, Inflasi, Interest

b. Dependent Variable: USD

\section{Uji F}

Dari uji F test, didapat F signifikansi 0,000 , lebih kecil dari 0,1 maka model regresi signifikan untuk memprediksi nilai tukar Rp/USD atau bisa dikatakan bahwa perbedaan variabel Gross Domestic Product, interest rate, inflation rate, dan posisi Balance Of Payment (Current Account \& Capital Account) secara bersamasama berpengaruh pada nilai tukar Rp/USD. Berarti Ho ditolak.

Koefisien Regresi

Persamaan Regresi : 
Nilai tukar Rp/USD $(\mathrm{Y})=2699.198-$ 6.442E-5 (yt-yt*) - 55.582 (rt-rt*) 60.970 (it-it*) + 5.971E-6 (bop1) 1.565E-5 (bop2)

Konstanta sebesar 2699.198 menyatakan bahwa jika tidak ada GDP, M2, suku bunga, dan Inflasi serta Balance of Payment, nilai tukar Rp/USD adalah Rp 2699.198 \$

Perbedaan GDP, suku bunga, dan Inflasi, capital account berbanding negatif terhadap nilai kurs, sedangkan current account berbanding positif terhadap nilai kurs.

\section{Pengujian variabel (Uji t)}

\section{Coefficients $^{\mathrm{a}}$}

\begin{tabular}{|c|c|c|c|c|c|c|}
\hline \multirow{2}{*}{\multicolumn{2}{|c|}{ Model }} & \multicolumn{2}{|c|}{$\begin{array}{c}\text { Unstandardized } \\
\text { Coefficients }\end{array}$} & \multirow{2}{*}{$\begin{array}{c}\begin{array}{c}\text { Standardized } \\
\text { Coefficients }\end{array} \\
\text { Beta }\end{array}$} & \multirow[b]{2}{*}{$\mathrm{t}$} & \multirow[b]{2}{*}{ Sig. } \\
\hline & & B & Std. Error & & & \\
\hline \multirow[t]{6}{*}{1} & (Constant) & 2699.198 & 730.452 & & 3.695 & .001 \\
\hline & Interest & -55.582 & 11.135 & -.459 & -4.991 & .000 \\
\hline & Inflasi & -60.970 & 14.473 & -.368 & -4.213 & .000 \\
\hline & BOP1 & $5.971 \mathrm{E}-6$ & .000 & .074 & .999 & .327 \\
\hline & BOP2 & $-1.565 E-5$ & .000 & -.322 & -4.521 & .000 \\
\hline & GDP & $-6.442 E-5$ & .000 & -.761 & -7.403 & .000 \\
\hline
\end{tabular}

a. Dependent Variable: USD

1. Variabel GDP mempunyai nilai $\mathrm{t}$ lebih kecil dari 0,05, yaitu 0,00, jadi variabel GDP berpengaruh secara negatif signifikan pada nilai kurs. Artinya jika semakin besar jumlah GDP indonesia dibandingkan dengan jumlah GDP Amerika, maka nilai kurs rupiah akan mengalami depresiasi.

2. Variabel Suku bunga mempunyai nilai t lebih kecil dari 0,05, yaitu 0,013, jadi variabel suku bunga berpengaruh secara negatif siginifikan pada nilai kurs. Artinya jika tingkat suku bunga Indonesia lebih besar dibandingkan tingkat suku bunga di Amerika, maka nilai kurs rupiah akan mengalami depresiasi. Walaupun suku bunga berpengaruh secara signifikan namun ternyata tidak sesuai dengan teori yang menjelaskan bahwa, jika tingkat suku bunga di Indonesia lebih tinggi maka nilai kurs rupiah akan mengalami apresiasi. Jadi dalam hasil ini, teori yang digunakan ternyata tidak sempurna, karena mungkin pada prakteknya para investor dalam menanamkan modalnya di suatu negara tidak hanya memperhatikan tingginya tingkat suku bunga, namun juga memperhatikan keadaan perekonomian yang sedang 
terjadi dalam negara terutama sektor rill, sehingga kepercayaan investor menjadi hal yang lebih penting dalam menanamkan modalnya. Pada faktanya, kasus di Indonesia, suku bunga yang tinggi tidak selalu menandakan perekonomian yang baik dan investasi yang menjanjikan, karena seringkali terjadinya suku bunga yang tinggi dikarenakan intervensi Bank Indonesia dalam rangka mengalihkan investasi di sektor finansial ke sektor rill. Oleh karena itu, suku bunga yang tinggi tidak selalu menarik investor, dengan demikian teori yang menyatakan bahwa semakin tinggi tingkat suku bunga dalam suatu negara akan membuat nilai kurs mata uangnya ter-apresiasi, tidak berlaku di Indonesia melainkan ter-depresiasi.

3. Variabel Inflasi mempunyai nilai $t$ lebih kecil dari 0,05, yaitu 0,005, jadi variabel inflasi berpengaruh secara negatif signifikan pada nilai kurs. Artinya jika semakin besar tingkat inflasi di Indonesia dibandingkan dengan tingkat inflasi di Amerika, maka nilai kurs rupiah akan mengalami depresiasi.

4. Variabel Current Account mempunyai nilai $\mathrm{t}$ lebih besar dari 0,05, yaitu 0,576, jadi variabel current account tidak berpengaruh secara positif signifikan pada nilai kurs. Artinya posisi current account Indonesia tidak menunjukan adanya pengaruh terhadap nilai tukar kurs. Hal ini dapat disebabkan karena nilai current account yang digunakan berlaku untuk transaksi keseluruhan negara (bukan hanya dengan Amerika)

5. Variabel Capital Account mempunyai nilai t lebih kecil dari 0,05 , yaitu 0,011 , jadi variabel capital account berpengaruh secara negatif signifikan pada nilai kurs. Artinya jika semakin besar surplus capital account Indonesia, maka nilai kurs rupiah akan mengalami depresiasi.

\section{PENUTUP \\ Kesimpulan}

1. Variabel Gross Domestic Product, interest rate, inflation rate,dan Balance Of Payment (Current Account \& Capital Account) secara bersama-sama berpengaruh pada nilai tukar Rp/USD.

2. Variabel Gross Domestic Product, interest rate, inflation rate,dan Balance of Payment, Capital Account berpengaruh secara negative signifikan secara parsial terhadap nilai tukar Rp/USD.

3. Variabel current account yang tidak berpengaruh secara signifikan parsial pada nilai tukar Rp/USD.

4. Angka adjusted $\mathrm{R}$ sebesar 0,844 menunjukan bahwa korelasi / hubungan nilai tukar Rp / USD dengan lima variabel independen-nya adalah sangat kuat, sedangkan sisanya $15.6 \%$ dijelaskan oleh faktor-faktor lain.

\section{Saran}


1. Untuk penelitian selanjutnya, agar lebih memperluas cakupan variabel penelitiannya, seperti menambahkan variabel GNP (Gross National Product), laju peredaran uang (Velositas), dan tingkat perubahan harga relatif, serta mencari objek negara pembanding yang lain seperti Cina, Inggris, ataupun Jerman.

2. Bagi para MNC (Perusahaan Multinasional) supaya lebih cermat dalam melihat gejolak perekonomian global, supaya tepat dalam menjalakan hedging dalam ber-transaksi internasional.

3. Memperbesar jumlah sampel.

\section{DAFTAR PUSTAKA}

Atmadja, Adwin Surja, (Vol. 4, No. 1, Mei 2002: 69 - 78), Analisa Pergerakan Nilai Tukar Rupiah Terhadap Dollar Amerika Setelah Diterapkannya Sistem Nilai Tukar Mengambang Bebas di Indonesia, Jurnal Akuntansi \& Keuangan, Fakultas Ekonomi : Universitas Kristen Petra

Bank Indonesia, (1999 - 2006), "Statistik Ekonomi Keuangan Indonesia", Jakarta.

Baillie, Richard dan Patrick McMahon,(1998), The Foreign Exchange Market: Theory and Econometric Evidence, Cambridge University Press, Cambridge.

Halwani, R.Hendra, (2002), Ekonomi Internasional dan Globalisasi Ekonomi, Jakarta : Ghalia Indonesia.
Isnowati, Sri, (Vol.9 No.1 Maret 2002 (Hal 107-119)), Analisis FaktorFaktor yang Mempengaruhi Nilai Tukar Rupiah Terhadap Dollar Amerika : Pendekatan Moneter 1987.2-1991.1, Jurnal Bisnis dan Ekonomi.

Kardoyo, Hadi dan Mudradjad Kuncoro, (2002), Analisis Kurs Valas Dengan Pendekatan BOXJENKINS: Studi Empiris Rp/US\$ dan Rp/Yen, 1983.2-2000.3, Jurnal Ekonomi Pembangunan : Kajian Ekonomi Negara Berkembang, Hal. 7-20.

Krugman, Paul R. \& Maurice Obstfeld, 2000, Ekonomi Internasional: Teori dan Kebijakan, Rajawali Pers Jakarta.

Madura, Jeff (2000), International Financial Management, USA: South-Western College Publishing.

Salvatore, Dominick (1997), International Economics, Sixth Edition, NewYork : John Wiley \& Sons, Inc.

Santoso, Singih, (2000), Buku Latihan SPSS : Statistik Parametrik, Jakarta : PT Elex Media Komputindo.

Sukirno, Sadono, (2002), Pengantar Teori Mikroekonomi, Edisi ketiga, Jakarta : PT. RajaGrafindo Persada

Wibowo, Tri dan Hidayat Amir, (Vol. 9 No. 4, Desember 2005), Faktor-Faktor yang Mempengaruhi Nilai Tukar Rupiah, Jurnal Kajian Ekonomi dan Keuangan, Jakarta : Departemen Keuangan RI. 